\title{
Sustainable Enjoyment of Economic and Social Rights in Times of Crisis
}

\author{
Obstacles to Overcome and Bridges to Cross
}

Natalie Alkiviadou ${ }^{*}$

Abstract

In 2008, the European Union was hit by the most severe financial downturn since the Great Recession of the 1930s. One of the major consequences of this phenomenon was the deterioration in the enjoyment of human rights, in particular economic and social rights. While it is indisputable that the crisis itself was directly correlated to the erosion of such rights, the conditions attached to the loan agreements between defaulting countries and the three lending institutions, namely the International Monetary Fund (IMF), the European Central Bank and the European Commission, have negatively affected the rights under consideration. Loans came with strict austerity measures, such as public expenditure cuts in the realm of, inter alia, public services, benefits and social security. This article considers the deterioration in the enjoyment of economic and social rights by Union inhabitants and particularly the anti-crisis strategy adopted by the European Union, which, as will be demonstrated, directly contributed to this deterioration. The stance of the three institutions was facilitated by the less than proactive, but improving, positioning of the Court of Justice of the European Union in case law, which will be assessed. It must be noted that it is not the three institutions acting alone in this process; the Member States are the ones who agree to the loans and their conditions and implement austerity measures on the ground. However, as will be reflected, the practical role and actual input of the countries themselves in this procedure is limited. The central theoretical tenet of the article is that the European Union is re-shifting its direction to the almost absolute adoption of an economic constitution, with little regard to its social counterpart. Within the aforementioned framework, this article seeks to assess the status of economic and social rights in a crisis-hit Union, provide a theoretical explanation for this occurrence and put forth possibilities for positive change, placing the protection and promotion of economic and social rights at the heart of any responses to crisis as a method to ensure their sustainable protection effectively.

Keywords: social and economic rights, austerity measures, Euro crisis, defaulting countries.

* Dr Natalie Alkiviadou is a Lecturer at the University of Central Lancashire Cyprus. 


\section{A Introduction}

In 2008, the European Union was hit by the most severe financial downturn since the Great Recession of the 1930s. ${ }^{1}$ One of the major consequences of this phenomenon was the deterioration in the enjoyment of human rights, in particular economic and social rights. A 2012 report of the Directorate-General for Employment, Social Affairs and Inclusion of the European Commission recognized that long-term unemployment associated with the crisis had reached such dire levels that "groups already at a heightened risk of poverty, such as young adults, children and to some extent migrants, are now experiencing an even worse situation". While it is indisputable that the crisis itself was directly correlated to the erosion of such rights, the conditions attached to the loan agreements between defaulting countries and the three lending institutions, namely the IMF, the European Central Bank and the European Commission, have negatively affected the rights under consideration. ${ }^{3}$ More specifically, loans came with strict austerity measures, such as public expenditure cuts in the realm of, inter alia, public services, benefits and social security. The Council of Europe Commissioner for Human Rights recognized the negative impact of austerity measures on the exercising of human rights. ${ }^{4}$ This situation, in relation to both the crisis itself and the strategies adopted to tackle it, has shaken the very foundations of the European Union. The financial crisis has come hand in hand with a social crisis in the form of the sharp fall in the standard of living of the Union's inhabitants and, in particular, of vulnerable groups. For example, a 2016 report of the European Parliament presents findings that demonstrates that, since 2008, the number of people living in the European Union who are at risk of poverty or social exclusion has risen in the majority of Member States. Those found to be at most risk are women, children, youngsters, single parent families, the less educated and migrants. ${ }^{5}$ Further, this crisis has been marked by a "decimation of employees' social rights, impoverishment among the lower and middle classes... [and] generalised precariousness". ${ }^{6}$ The financial and social dismay has facilitated the development of a political crisis, as can be seen, for example, by the rise to power of Fidesz in Hungary and PiS in Poland, the electoral rise of far-right groups, such as Golden Dawn in Greece, which currently holds third place in parliament and the

1 Fundamental Rights Agency, The European Union as a Community of Values: Safeguarding Fundamental Rights in Times of Crisis, 2013, p. 5.

2 European Commission, Directorate-General for Employment, Social Affairs and Inclusion, Employment and Social Developments in Europe 2012, 2012.

3 V. Engström, 'The Political Economy of Austerity and Human Rights Law', Institute for Human Rights Working Paper No. 1/2016, 2016, p. 1.

4 Report of the United Nations High Commissioner for Human Rights, The Impact of Austerity Measures on Economic, Social and Cultural Rights, 7 May 2013, E/2013/82; Council of Europe, Commissioner for Human Rights, 'Safeguarding Human Rights in Times of Economic Crisis', Issue Paper, 2013, p. 2, 4 December 2013.

5 European Parliament, Poverty in the European Union: The Crisis and its Aftermath (March 2016: PE579:009), p. 1.

6 D.V. Whitehead, The European Social Model in Crisis: Is Europe Losing Its Soul? Cheltenham, UK, Edward Elgar; Geneva, ILO, 2015. 
victory of nationalism at the latest European elections. ${ }^{7}$ Moreover, as pertinently argued, "one of the most evident effects of the economic crisis is that it has turned into a sort of existential crisis for the EU as a whole". ${ }^{8}$ Although the economic, social, political and existential crisis of the EU are interrelated, this article will focus solely on the social aspect of the crisis and namely the deterioration in the enjoyment of economic and social rights by Union inhabitants. As will be demonstrated in this article, the lenders placed emphasis on finances and saving the Eurozone, with less regard to the social element of such measures. In fact, it could be argued that the anti-crisis strategy of the EU, namely loans (with strict conditions) granted to Member States, has been just as threatening to the European integration process, core Union values, such as solidarity, and the welfare of its inhabitants as the crisis itself, given that focus was placed absolutely on the restoration of the economy even if this meant disregard for the social objectives and provisions of the EU legal framework. ${ }^{9}$ Fitzpatrick holds that, particularly in the post-Lisbon era, the EU's social constitution made up by the Charter, the social provisions of the treaties and the social acquis result in a strong argument against the disregard for social and economic rights in relation to the design and implementation of austerity measures as conditions for lending. ${ }^{10}$ As such, and ironically enough, the design and implementation of the anti-crisis strategy occurred during a time when human rights have been more recognized and embraced than ever and, more significantly, have taken place post-Lisbon, a period during which there has been a "new impetus to a fundamental rights culture in the EU's institutional structure". ${ }^{11}$ The stance of the three institutions was facilitated by the less than proactive, but improving, positioning of the Court of Justice of the European Union (CJEU) in case law, which will be assessed hereinafter. It must be noted that it is not solely the three institutions acting alone in this process; the Member States are the ones that agree to the loans and their conditions and implement austerity measures on the ground. However, as will be demonstrated in this article, the practical role and actual input of the countries themselves in this procedure is limited. The situation described above demonstrates a shift to an economic constitution of the EU. The concept of an economic constitution was initially developed by the German ordoliberal school. More particularly, the Freiburg school founders developed the idea of the economic consti-

72014 European Parliament elections: victories of parties such as France's Front National (National Front), UKIP and Denmark's Dansk Folkeparti (The Danish People's Party), with the parties gaining $24.86 \%, 26.77 \%$ and $26.60 \%$ of the vote respectively, finding themselves at the top of the list for their countries. Violent far-right parties are also part of the European Parliament with Golden Dawn receiving $9.39 \%$ of the vote and Hungary's Jobbik Magyarországért Mozgalom receiving $14.67 \%$ of the vote in 2014 in third and second place respectively.

8 A. Baraggia, 'Conditionality Measures Within the Euro Area Crisis: A Challenge to the Democratic Principle?', Cambridge Journal of International and Comparative Law, Vol. 4, No. 2, 2015, p. 268.

9 F. Costamanga, 'Saving Europe "Under Strict Conditionality": A Threat for EU Social Dimension?', LPF Working Paper, 2012, No. 7, p. 1.

10 C. Kilpatrick, 'Are the Bailouts Immune to EU Social Challenge Because They Are Not EU Law?', European Constitutional Law Review, Vol. 10, No. 3, 2014, p. 393.

11 Fundamental Rights Agency. 'The European Union as a Community of Values: Safeguarding Fundamental Rights in Times of Crisis', 2013, p. 7. 
tution, that being "the institutional framework within which economic activities take place". ${ }^{12}$ As noted by Drexl, the concept of a European economic constitution is widely used in scholarly analysis of different languages of the EU. ${ }^{13}$ Among these scholars are Tuori and Tuori, who set the theoretical framework of their analysis of the Eurozone Crisis by relying on five constitutions. The economic constitution, which has the economy as the main constitutional object; the juridical constitution, which focuses on the legal system; the political constitution, which embraces European polity as the object; the security constitution, which looks at security risks; and the social constitution, which works on the social welfare of EU citizens. The economic and social constitution and the comparison between the two will constitute the theoretical framework through which the treatment of social and economic rights in the financial crisis of the Union shall be appraised in this working paper. The argument that the economic constitution has superseded the other constitutions will be demonstrated by three illustrations, namely, the austerity measures themselves, the passive stance of the CJEU and the fact that the European Parliament has no role in any austerity-related process. As such, the objectives of the article are to assess the status of economic and social rights in a crisis-hit Union, provide a theoretical explanation for this occurrence and put forth possibilities for positive change, placing the protection and promotion of economic and social rights at the heart of any responses to crisis as a method to ensure their sustainable protection effectively.

\section{B Economic and Social Rights: An Overview}

The protection of human rights, including economic and social rights, were not part of (what we now call) the European Union's initial architecture. As reflected in the substance (and naming) of the 1957 Treaty establishing the European Economic Community, this was an economic project. European integration was equated to economic integration pursued through the establishment of a common market. However, some elements of social rights and social protection were incorporated in the Treaty of Rome. For example, Article 117 of Title III on Social Policy provides for the improvement of working conditions and standard of living for workers. Another example is Article 123 establishing the European Social Fund for improving employment opportunities and raising the standard of living of workers in the common market and these social rights were directly correlated with the common market and the free movement of workers. However, the architecture of the Union developed, as reflected in the change of name and, importantly in the developments of the post-Lisbon era. The Charter of Fundamental Rights of the European Union (Charter) is the central EU document that provides for human rights. Post-Lisbon, it enjoys legal status equivalent to treaties. Importantly, this document provides for civil and political rights as well as economic

12 V.J. Vanberg, 'The Freiburg School: Walter Eucken and Ordoliberalism', Walter Eucken Institute - Freiburg Discussion Papers on Constitutional Economics 4/11, 2011, p. 7.

13 J. Drexl, 'La constitution économique européenne - L'actualité du modèle ordolibéral', Revue Internationale de Droit Economique, Vol. 15, No. 4, 2011, pp. 419-454. 
and social rights, significantly distinguishing it from the European Convention on Human Rights, which focuses heavily on first generation rights. Title II on Freedoms provides for both first and second generation rights, with the latter including the right to education (Art. 14), freedom to choose an occupation and right to engage in work (Art. 15) and right to property (Art. 17). Title II on Equality recognizes the particular rights of groups, namely the elderly and children and underlines the equality between men and women. These are groups which, among others, have been particularly vulnerable in the crisis. In fact, Title IV of the Charter on Solidarity further develops the Union's framework in relation to economic and social rights and is one of the most extensive parts, therein, setting out 12 articles on rights such as protection in the event of unjustified dismissal (Art. 30), fair and just working conditions (Art. 31), social security and assistance (Art. 34) and health care (Art. 35). Precisely half of the articles of this Title provide that they are recognized in accordance with national laws and practices, thereby, giving leeway to Member States in the framework of their conceptualization and exercise. Although Article 52(6) holds that "full account shall be taken of national laws and practices as specified in this Charter", there is no incorporation of this element in articles on civil and political rights or in the generic economic and social rights recognized in Title II. Either way, and notwithstanding reference to national practices in relation to Title IV, the Charter directly provides for economic and social rights and, by constituting primary EU Law, imposes the obligation on the EU institutions and the EU Member States to respect these rights. Article 51 on the field of application holds that the Charter provisions are addressed to Union institutions with due regard to the principle of subsidiary and to Member States only when they are implementing Union Law. As will be discussed in Section F, this article was the one initially relied upon by the CJEU to wash its hands of any responsibilities vis-à-vis the deterioration of rights as a result of the anti-crisis strategy adopted.

In addition to the Charter provisions and its post-Lisbon legal value, the human rights framework of the EU and, for purposes of this article, the social landscape of the Union has been enhanced by other post-Lisbon mechanisms, such as Article 3(3) of the TEU which, within the framework of the internal market, refers to, inter alia, social progress, combatting of social exclusion and discrimination, promotion of social justice and protection. This article views the internal market as 'an EU objective in its own right' and, in addition, directly correlates the establishment of this market with the pursuit of the above objectives. ${ }^{14}$ Further, Article 9 of the TFEU provides that, in defining and implementing its policies and activities, the Union shall take into account requirements linked to the promotion of a high level of employment, adequate social protection, the fight against social exclusion, a high level of education and training and a high level of human health. In sum, particularly as a result of the developments brought about by the Lisbon Treaty, the EU has a human rights document, which constitutes primary EU Law and incorporates both civil and political rights and

14 A. Koukiadaki, 'Can the Austerity Measures Be Challenged in Supranational Courts? The Cases of Greece and Portugal', University of Manchester, An analysis for the ETUC, 2014, p. 20. 
social and economic rights. In addition, Article 3(3) of the TEU and Article 9 of the TFEU enhance the social geography of the Union and enhance the institutions' obligations to consider and promote social and economic rights within the Union. Notwithstanding the new human rights impetus within the EU setting and the reality that human rights recognition is greater than ever before, human rights as a tenet covering social development as well through, for example, the right to work and social security, did not constitute a tenet in the design and implementation of anti-crisis measures. As noted by Saiz, "despite the obvious human rights dimension of the crisis, human rights have barely figured in the diagnosis or prescriptions proposed by the international community". ${ }^{15}$ As such, the complete disregard of human rights is not just bad practice but a breach of primary EU Law and renders the theoretical commitment of the EU to the promotion of social justice null and void. The dismal human face of the crisis that came about as a result of the crisis itself and the strict austerity measures, has been marked by poverty and social exclusion, particularly of vulnerable groups, thereby, limiting or even nullifying the enjoyment of rights provided for in the Charter. ${ }^{16}$ Examples, for purposes of demonstrating the deterioration of the standard of living of persons living in the EU, and particularly those belonging to vulnerable groups, are many but two will be put forth for purposes of a brief illustration,. The European Federation of National Organisations working with the homeless identified a systematic pattern of more homeless migrants due to welfare and housing cuts, ${ }^{17}$ while the UN High Commissioner for Human Rights noted that cuts in public expenditure are impacting disabled persons "in a particularly harsh way". ${ }^{18}$

Economic and social rights have been adversely impacted by the crisis itself and include, for example, the rise in unemployment, which has led to, inter alia, a deterioration of the right to work and the right to an adequate standard of living. Economic and social rights have been further eroded by the anti-crisis response through the imposition of austerity measures by the 'institutions' and their adoption by the Member States. In this realm, two issues are of central importance to further understanding the status quo of economic and social rights in a crisis framework. First, the relative ease in which the anti-crisis strategy managed to circumvent sincere consideration of economic and social rights and, second, the relative perplexity in demonstrating the violation of economic and social rights in the Union's anti-crisis strategy. One of the reasons that could explain both issues at least in part, could be the very nature of economic and social rights, their progression and the perceived non-justiciability of these rights. Article 2 of the International Covenant on Economic, Social and Cultural Rights (ICESCR) holds that each state party shall, to the maximum of its available resources, undertake steps

I. Saiz, 'Rights in Recession? Challenges for Economic and Social Rights Enforcement in Times of Crisis', International Journal of Human Rights Practice, Vol. 1, 2009, p. 280.

16 A. Baraggia, 'Conditionality Measures Within the Euro Area Crisis: A Challenge to the Democratic Principle?', Cambridge Journal of International and Comparative Law, Vol. 4, No. 2, p. 275.

17 Fundamental Rights Agency, The European Union as a Community of Values: Safeguarding Fundamental Rights in Times of Crisis, 2013, p. 12. Ibid., p. 13. 
Figure 1 Articles taken from the Charter on Fundamental Rights of the European Union

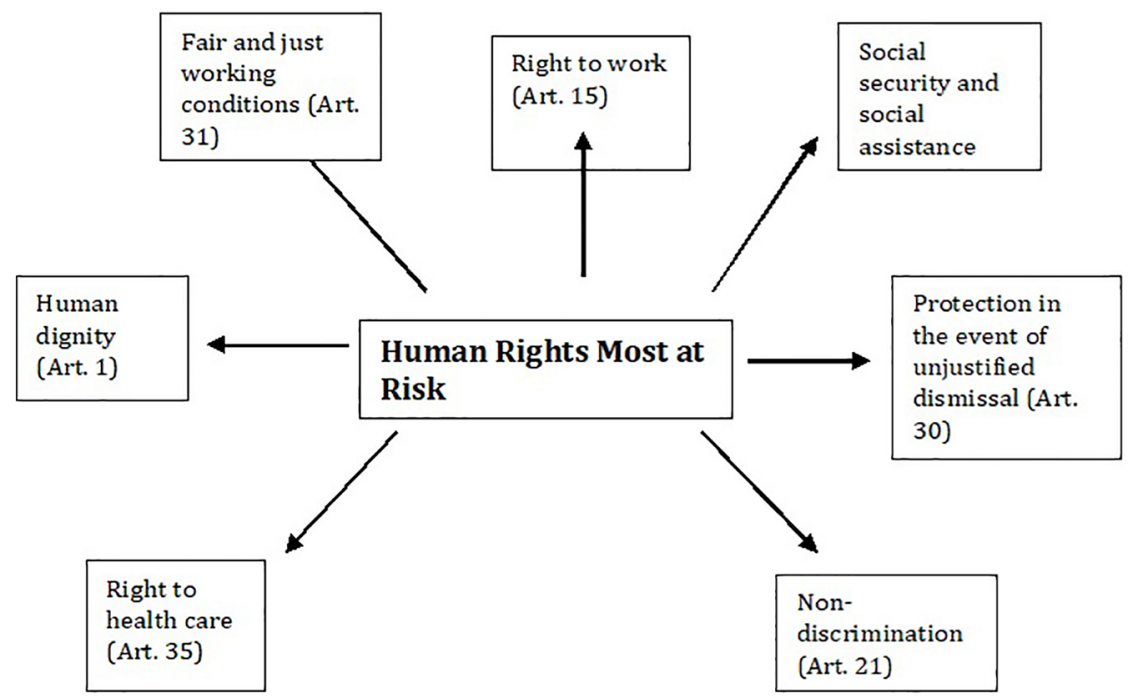

"with a view to achieving progressively the full realisation of the rights". Therefore, the Covenant recognizes that economic and social rights need time, progress and processes to be developed and achieved and that this achievement may be affected by economic factors. Moreover, it has been argued that the permissibility of retrogressive measures is ingrained in economic and social rights. More specifically, when the economy is in a bad state, "retrogressive measures become an expression of the flexibility inherent in the idea of progressive achievement" ${ }^{19} \mathrm{In}$ relation to justiciability within the framework of austerity, the role of the judiciary in appraising austerity measures and their impact on economic and social rights has been discussed by the European Court of Human Rights in Koufaki and Adedy v. Greece. There, the Court held that

...the decision to enact laws to balance State expenditure and revenue will commonly involve consideration of political, economic and social issues and the margin of appreciation available to the legislature in implementing social and economic policies is a wide one.

This makes it clear that the Court feels that it is beyond the scope of their mandate, as a judicial body, to make such political, economic and social decisions. In addition, the Court underlined that states parties have "quite a wide margin of

19 Committee on Economic, Social and Cultural Rights, General Comment No. 9 (The domestic application of the Covenant), para. 1. Also see General Comment No. 15 (Right to Water), para. 45. 
appreciation in regulating their social policy". ${ }^{20}$ In addition, the Court underlined the principle of proportionality and its role in such policies. More particularly, the Court attached "particular weight to the reasons given by the Supreme Administrative Court", which dismissed several arguments that the measures had breached the proportionality principle. The positions put forth by the Supreme Administrative Court included that the measures in question sought to consolidate the state's finances in a sustainable manner. ${ }^{21}$ As such, the difficulty which lies in bringing economic and social rights before a court, the permissibility provided to states progressively to realize such rights, in line with their economic resources, the margin of appreciation granted to states to fulfil certain obligations as well as the principle of proportionality simply make this group of rights the weakest link.

\section{Theoretical Framework: A Dominant Economic Constitution?}

As noted in the introduction, the premise of this article is that, as a means to tackle the crisis, the Union's approach was a financial one, facilitated by the prioritization of the EU's economic constitution. Tuori and Tuori propose five European constitutions, namely economic, juridical, political, security and social. ${ }^{22}$ The authors understand the European constitution as a "multi-dimensional and multi-temporal process of constitutionalisation where periods of dominance of a particular pacemaker constitution are distinguishable" ${ }^{23}$ The temporality is affected by the particular period and setting of the EU at the time. For example, the Eurozone crisis has led to the prioritization of the economic constitution with the economic constitution not approaching economic growth and social cohesion as interrelated and interdependent. This approach has facilitated the disregard for social and economic rights in the framework of the anti-crisis strategy and, as well as impacting the enjoyment of these rights by the inhabitants of the EU, in particular vulnerable groups, it places the European integration process and the values of the EU, as enshrined in Article 2 of the TEU, at risk. More particularly, it could be argued that the integration process itself is viewed from a merely financial and economic perspective. This demonstrates a regression to the economic integration model adopted by the Treaty of Rome, while the core European values of Article 2, and particularly human dignity and respect for human rights, have taken a back seat in the response to the crisis. Further, the principle of solidarity features in the Preamble of the TEU as well as other articles, such as Article 2, which provides that values such as the ones referred to above are common to the Member States in a society in which, inter alia, solidarity prevails and Article 3, which holds that the Union shall promote solidarity among Member States. Further, Article 120 of the TFEU, in the chapter on Economic Policy, stipulates that

Ibid., para. 44.

K. Tuori \& K. Tuori, The Eurozone Crisis: A Constitutional Analysis, New York, Cambridge University Press, 2014, p. 4.

Ibid., p. 10. 
Member States shall "conduct their economic policies with a view to contributing to the achievement of the objectives of the Union, as defined in Article 3 of the Treaty on the European Union". Article 3 provides for, among others, the promotion of solidarity among Member States. Article 120 TFEU, therefore, sets out a distinct interrelation between the promotion of solidarity and economic policies as conducted by Member States (not EU institutions). The Preamble of the Charter holds that the Union is founded on, inter alia, the value of solidarity. The Charter contains a chapter entitled Solidarity, which deals with a range of economic and social rights which were directly put at risk in the Union's anti-crisis strategy. Article 51, therein, holds that the Charter's provisions are addressed to its institutions as well as Member States (when they are implementing Union Law). As will be reflected in the case-law analysis, this article was of direct relevance to the subject under consideration and the mechanism through which the 'institutions' were found not to breach Charter provisions. Although solidarity is emphatic in treaties, it is not defined anywhere, therein, making its conceptualization difficult but also rendering the determination of legal implications arising, thereof, almost impossible. The only indicator that one may allude to is the fact that solidarity was the chosen name for the Charter's provisions on, among others, work and social security conditions. This, at least, demonstrates a correlation between solidarity and the requirements of solidarity, on the one hand, and socio-economic development, cohesion and justice on the other. It would be hard to argue, as will be extrapolated on in the section below, that the Union's anticrisis strategy gave any due regard to such issues. This position is summed up in Mario Draghi's statement that "we will do anything it takes to preserve the Euro". ${ }^{24}$ Essentially, this was the approach taken by the 'institutions', with the social constitution of the EU suffering not only as a result of the anti-strategy focus being on finances and the economy but, also, because the measures adopted within this strategy directly impact the social strata of the EU and, particularly, the social and economic rights of its inhabitants. In a nutshell, it appears that the interests of the Union have regressed to the times of almost absolute prioritization of economic integration. Related to this is that the anti-crisis strategy put forth by the 'institutions' and implemented by Member States, which demonstrates that solidarity appears to be financial solidarity for purposes of keeping the Eurozone afloat.

\section{Towards an Economic Constitution? Part 1 - Austerity}

\section{Austerity Measures and Their Impact on Social and Economic Rights}

Austerity measures are a central tenet of the anti-crisis strategy adopted by the Union, given that they came as part and parcel of the loan granted to defaulting Member States as conditions for financing. In 2010, EU Member States set up the European Financial Stabilisation Mechanism (EFSM) and, in 2011, the European

24 J. Dunkley, 'Debt Crisis: Mario Draghi Pledges to do “Whatever it takes” to Save Euro', The Telegraph, 26 July 2012, available at: www.telegraph.co.uk/finance/financialcrisis/9428894/Debtcrisis-Mario-Draghi-pledges-to-do-whatever-it-takes-to-save-euro.html (accessed 30 June 2017). 
Financial Stability Facility (EFSF) to provide future loans. ${ }^{25}$ In 2012, the European Stability Mechanism replaced these two and is an international financial institution established by the European Stability Treaty. The ESM "elude[s] any kind of democratic accountability...nor are its operations subject to constraints of the EU legal system" ${ }^{26}$ It aims at mobilizing funding and providing stability support under 'strict conditionality' to the benefit of ESM members who are experiencing or threatened with severe financial difficulties if such funding and support are "indispensable to safeguard the financial stability of the euro area as a whole and of its Member States". 27 The conditionality referred to in the ESM Treaty has been attached to all lending processes during the crisis, constituting a 'prominent feature 28 of these processes, notwithstanding the form or name of the lending institution or institutions. Austerity measures imposed included, enforced cuts in public expenditure in fields such as social security and access to health care. ${ }^{29}$ One of the many examples of such cuts is illustrated in Council Decision 2011/734/EU, which required, among others, a reduction in pay rates for overtime work, reduction in pharmaceutical expenditure by social security and freezing in the indexation of pensions. ${ }^{30}$ As argued, 'scant attention' ${ }^{31}$ was placed on the social implication of such measures, demonstrating the restricted focus adopted by the lenders to the crisis, with fiscal issues constituting their only priority. In 2011, in agreements with Ireland and Portugal, the lenders incorporated clauses on the social impact, noting that the lenders would "review the social impact of the agreed measures" and recommend necessary corrections in order to "minimise harmful social impacts, particularly on the most vulnerable parts of the society" ${ }^{32}$ However, this did not appear to bear too much fruit as it did not translate into practical assessment of impact. The anti-crisis strategy of the EU, as developed and facilitated in the framework of an economic constitution, was developed in the second decade of the twenty-first century, notwithstanding lessons learnt in lending processes to developing countries during the 1980s and 1990s by the World Bank and the IMF. After a series of studies conducted within this framework, the design of austerity measures should take into account the protection of vulnerable groups. ${ }^{33}$ Notwithstanding these clauses, the lenders still placed priority on finances at the expense of social issues. ${ }^{34}$ In fact, austerity measures are

\section{Kilpatrick, 2014, p. 399.}

B. de Witte, 'The European Treaty Amendment for the Creation of a Financial Stability Mechanism', European Policy Analysis, Vol. 6, 2011, p. 846.

ESM Treaty, 2012, Art. 3.

F. Costamanga, 'Saving Europe "Under Strict Conditionality": A Threat for EU Social Dimension?', LPF Working Paper, No. 7, 2012, p. 6.

Ibid., p. 9.

Ibid., p. 10.

Ibid.

Added to Council Implementing Decision 2011/77/EU (Art. 3.9) and Council Implementing Decision 2011/344/EU (Art. 3.10) concerning respectively Ireland and Portugal.

3 Fundamental Rights Agency Working Paper, 'Protecting Rights during the Economic Crisis', 2010, p. 14.

F. Costamanga, 'Saving Europe "Under Strict Conditionality": A Threat for EU Social Dimension?', LPF Working Paper, No. 7, 2012, p. 11. 
such a centrifugal part of the Union's approach that Fitzgerald refers to them as a "new and highly significant source of social norms in the EU". ${ }^{35}$ As well as directly damaging economic and social rights, austerity measures have also hampered the work and activity of human rights institutions, such as Equality Bodies and civil society organizations, ${ }^{36}$ which subsequently affects the promotion and protection of, inter alia, economic and social rights. The negative impact of austerity measures on such institutions was also underlined by the Council of Europe Commissioner on Human Rights in his report on crisis-hit countries, such as Cyprus, urging authorities to avoid budgetary cuts of human rights institutions. ${ }^{37}$ A worrying development in the international community, in relation to the acceptability of austerity measures, was a letter dated 16 May 2012 from the Chairperson of the Committee on Economic, Social and Cultural Rights to states parties to the ICESCR. The Chairperson reiterated the need to avoid taking decisions that may violate economic, social and cultural rights as this is contrary to their obligations under the Covenant and can also lead to social and political instability and the further marginalization of vulnerable groups. The Chairperson defines vulnerable groups to include, among others, the poor, women, children, persons with disabilities, older persons, people with HIV/AIDS, indigenous people, ethnic minorities, migrants and refugees. However, the letter holds that the Committee "realises that some adjustments in the implementation of some Covenant rights are at times inevitable". ${ }^{38}$ The letter refers to times of emergency but offers no definitional framework of what is to constitute an emergency. After recognizing the possibility that rights might have to be restricted in times of crisis, the Committee placed some, albeit generalized and abstract, safeguards into the conceptualization of austerity measures, discussed in Section F.II. Thus, the Committee endorses the crisis narrative of necessity in the restriction of social and economic rights and inflates "the importance of neo-liberal market-based ideals". ${ }^{39}$ This argument is also in direct opposition to previous positions of the Committee, which reminded states that this genre of rights is even more, rather than less, significant in times of crisis. ${ }^{40}$ The letter, thus, has the capacity to alter the focus and importance on non-retrogression to a model of emergency justification of rights' limitations. ${ }^{41}$ This was, therefore, a worrying development since the leading international institution on the promotion of economic, social and cultural

35 Kilpatrick, 2014, p. 399.

36 Fundamental Rights Agency, 'The European Union as a Community of Values: Safeguarding Fundamental Rights in Times of Crisis', 2013, p. 31.

37 Report by the Commissioner for Human Rights of the Council of Europe following his visit to Cyprus from 7-11 December 2015, para. 114.

38 Letter dated 16 May 2012 addressed by the Chairperson of the Committee on Economic, Social and Cultural Rights to States parties to the International Covenant on Economic, Social and Cultural Rights, CESCR/49th/SP/MAB/SW.

39 B.T.C. Warwick, 'Socio-Economic Rights during Economic Crises: A Changed Approach to NonRetrogression', International and Comparative Law Quarterly, Vol. 65, No. 1, 2015, p. 255.

40 Committee on Economic, Social and Cultural Rights, General Comment 2: International Technical Assistance Measures (UN Doc. E/1990/23, 1990).

41 B.T.C Warwick, 'Socio-Economic Rights during Economic Crises: A Changed Approach to NonRetrogression', International and Comparative Law Quarterly, Vol. 65, No. 1, 2015, p. 254. 
rights acceded to the position that restriction of such rights is a necessary part of a state's response to a crisis. This is even more worrying when taking into account the response of the EU to these rights in its anti-crisis strategy and the nature of economic and social rights as progressively realizable. These, taken together with the position adopted by the Committee in the single letter on this group of rights and the crisis, do not create a positive benchmark to be pursued.

In its Resolution 1884 (2012), the Parliamentary Assembly of the Council of Europe raised its concern that the restrictive approaches currently pursued predominantly based on budgetary cuts in social expenditure may not reach their objective of consolidating public budgets, but risk further deepening the crisis and undermining social rights as they mainly affect lower income classes and the most vulnerable categories of the population.

The Fundamental Rights Agency of the EU (FRA) has argued that, depending on their design, austerity measures can "threaten to adversely affect lowerincome and vulnerable groups". ${ }^{42}$ The central tension is, therefore, between the focus on economic redevelopment through loan agreements that come with strict conditions without the analogous consideration on the damaging effect of the austerity measures on the social strata of the countries. What is far from a reality is the integration of social considerations in the form of the promotion and protection of social and economic rights as an avenue for fiscal regeneration. This position is in contravention to post-Lisbon Europe where provisions, such as Article 3 TEU, integrate the need to combat social exclusion and promote social justice and where Article 9 TFEU requires the Union to take into account requirements linked to, inter alia, social protection and the fight against social exclusion when designing and implementing its policies. In fact, these provisions become almost a hypocritical facade when considering the nature and effects of the austerity measures that have been linked to loans granted to defaulting countries with no demonstration of, at least, an effort, on the part of the 'institutions,' to carry out a balancing exercise between financial and social considerations and a questionable ability of Member States to manoeuvre within this framework. In fact, the discrepancies between what is set out in treaties in relation to social justice and economic and social rights, on the one hand, and the anti-crisis strategy enforced, on the other, reinforce the case for legally challenging austerity measures. ${ }^{43}$ It is, therefore, evident that "rapid fiscal consolidation and structural reform have created a cascade of social instructions", ${ }^{44}$ which demonstrate a prioritization of Europe's economic rather than social constitution with the former not taking into account or embracing the social aspects and implications of its actions. However, notwithstanding the technical and conceptual validity of this argument, as will be demonstrated in Section F, the CJEU has been wary in its approach and involvement, at least initially. However, in brief, and following Ledra Advertising discussed below, the functioning of the two EU institutions act- 
ing under the ESM can be brought before the CJEU and, as such, the status of the ESM as an international organization does not relieve EU institutions from responsibility under EU Law. In fact, as noted by Laulhé-Shaelou and Karatzia, Ledra Advertising was the first time that the CJEU both reviewed the actions of an EU institution under the ESM and "pronounced the applicability of the Charter to the EU institutions when they act outside the EU legal framework" ${ }^{45}$

\section{Austerity Measures: Beyond EU Competences?}

In the above section, it was demonstrated that, immediately following the onset of the crisis, the EU rigidly embraced an economic constitution, without due regard for the requirements of its social counterpart. It must be emphasized that there exists no legal reason to prevent the equal development of social policy and economic policy as provided for by the Treaty on the European Union and further developed by the Treaty on the Functioning of the European Union. However, the reality is that there was no equality in the development of these policies, with the social counterpart remaining almost untouched. The lack of legal justification and the depiction of the EU as an entity with strong focus on economic elements demonstrate that this inequality stems from lack of political will for social consideration. ${ }^{46}$ As a result, fiscal consolidation was the driver of anti-crisis strategies with the 'institutions' incorporating austerity measures that paid little or no attention to their social implications. Another indicator showing the shift to an economic constitution was the extended competences granted to the institutions. More particularly, proposed austerity measures impacted several aspects of, for example, welfare regimes of affected countries "in a way that seems to go far beyond the limits imposed by the treaties to the EU capacity to intervene in this field". ${ }^{47}$ In fact, in a post-Lisbon EU, Article 5 TEU reaffirmed the principle of conferral, while Article 153 TFEU reflects the limited scope of the Union in the framework of social policy by providing that the Union shall 'support and complement' the activities of Member States in social fields, such as social security and social protection of workers. Importantly, Article 153(4) provides that the provisions of the article shall not affect the right of Member States to define the fundamental principles of their social security systems and must not significantly affect the financial equilibrium thereof. Essentially, nowhere in the treaties can one find a legislative basis for the actions of these institutions in relation to the austerity measures they imposed on Member States and which directly limited social and economic rights and the social policy and justice objectives pursued in Article 153. This is notwithstanding that Article 13(2) provides that each institution of the Union (including the European Commission and the European Central Bank) shall act within the limits of the powers conferred on it in the treaties, and in conformity with the procedures, conditions and objectives set out in them. In a mentary on Mallis and Ledra', European Law Review, 2017 (forthcoming).

46 This was one of the conclusions of a Jean Monnet Conference entitled 'The Sustainability of Socio-economic Rights in Times of Crisis' (3-4 July, UCLan Cyprus). 
nutshell, the 'institutions' encroached on themes and issues that are within the competence of Member States, rather than the EU, all in the name of its anti-crisis strategy and all in the framework of a hard-line economic constitution.

In looking at the issue of economic integration as the paradigm of European solidarity, it is also necessary to consider the implications on Member States who are part of the Economic and Monetary Union and, particularly, their reduced leeway in tackling the crisis as a result of their membership thereto. For example, instruments to tackle national adjustments such as exchange rate and policy instruments would no longer be available for EMU members. This has led to the need for establishing fiscal adjustment mechanisms, would need to be created. ${ }^{48}$ It must be noted that this article does not look at whether or not the Union should have offered financial assistance to Member States but, rather, critically assesses the nature of this assistance in light of the very foundation of the Union, which is no longer only economic strengthening of the Union but, also, the protection and promotion of social values which are necessary pre-requisites for a fair, just and functioning democracy.

In light of the measures attached to loan agreements and the lack of national adjustment tools to EMU members, the next important question is what is the actual role of Member States who need to impose austerity measures on the ground? Did they and do they have leeway for avoiding their implementation, debating their content or reducing their social impact? Evidence shows that countries, such as Greece, had "little room for manoeuvre, questioning the idea of sole state responsibility for the measures" 49 given that the measures imposed were put forth as a condition and were designed and described in great detail. Therefore, framing the measures in such a way as to limit the involvement and reaction of Member States facilitated the central objective of the Union, which was none other than fiscal consolidation as comprehended and pursued within the ambit of its economic constitution.

\section{Austerity Measures: The Role of Parliaments}

As noted by the FRA, "countries do much better in responding and dealing with economic crises when transparency in decision-making is promoted". ${ }^{50} \mathrm{On}$ a Member State level, national parliaments were "widely conceived as mere executors of policies imposed from the outside". ${ }^{51}$ In its Resolution 1884 (2012), the Parliamentary Assembly underlined the need to maintain democratic legitimacy in relation to decisions taken within the anti-crisis framework by "preserving maximum possible discretion for national governments and other national democratically legitimated institutions". As noted by Scharpf, "European responses to

48 As noted in the Calmfors Report on the EMU and the advantages and disadvantages of joining a single currency. Available at: http://uk.euabc.com/word/128.

49 V. Engström, 'The Political Economy of Austerity and Human Rights Law', Institute for Human Rights Working Paper No. 1/2016, 2016, p. 13.

50 Fundamental Rights Agency Working Paper, 'Protecting Rights during the Economic Crisis', 2010, p. 14.

51 Tuori \& Tuori, 2014, p. 11. 
the euro crisis have disabled national democratic legitimacy". ${ }^{52}$ This primarily resulted from the drastic reduction of Member State sovereignty in relation to the anti-crisis strategy. As such, democratic legitimacy of the implementation of austerity measures was drastically reduced. Further, the European Parliament is the only elected body of the European Union and notwithstanding its crucial role for upholding democracy within the Union, it has not been part of the anti-crisis strategy. For example, the European Parliament has been granted no powers within the European Stability Mechanism. In fact, after considering the draft of the Council Decision on the establishment of the ESM, the parliament put forth recommendations regarding amendments to Article 136 and, in particular, that the rules for conditionality should be determined by a regulation adopted under co-decision. ${ }^{53}$ However, the recommendation was not taken into consideration by the European Council which, instead, enhanced the role of the unelected European Commission.

In brief, national parliaments and the European Parliament have been granted 'but a peripheral position' 54 in the tools, strategies and mechanisms adopted in the realm of the Union's anti-crisis strategy. This occurred even though, postLisbon, the role of democracy and significance of transparency have been underlined and the powers of the European Parliament enhanced. Essentially, the anticrisis strategy embraced, a "kind of executive federalism...that would provide the template for a post-democratic exercise of political authority". ${ }^{55}$ Once again, the lack of democratic input on a national or European level reflects the prioritization of the economic constitution, at the expense of the Union's political constitution and with potential impact on social aspects given that no elected body was mandated to have a sincere and effective role in the design of the anti-crisis strategy.

\section{E Towards an Economic Constitution? Part 2 - Judicial Protection}

In ascertaining whether the absolute prioritization of the Union's economic constitution is a reality, it is imperative to consider the issue of judicial protection in the framework of the Eurozone crisis and, in particular, the role of the CJEU in ensuring judicial protection. The central question to be responded to in this section is how the CJEU positions itself in the framework of this economic constitution where fiscal consolidation accompanied by strict conditionality was the 'institutions' approach as facilitated by the aforementioned enhanced competences of the EU (regardless of Treaty limitations).

52 Ibid., p. 201

53 European Parliament Resolution of 23 March 2011 on the Draft European Council Decision amending Art. 136 of the Treaty on the Functioning of the European Union with regard to a stability mechanism for Member States whose currency is the euro [2011] P7_TA(2011)0103.

54 Tuori \& Tuori, 2014, p. 211.

55 J. Habermas, The Crisis of the European Union: A Response (Ciaran Cronin tr.), Cambridge, Polity Press, 2012, p. 7. 


\section{Article 263 TFEU: Threshold Obstacles}

Article 263 TFEU provides that the CJEU shall review the legality of legislative acts, acts of the Council, of the Commission and the European Central Bank, other than recommendations and opinions and acts of the European Parliament and the European Council intended to produce legal effects vis-à-vis third parties. This is, therefore, the central framework through which the legality of measures adopted within the anti-crisis strategy of the Union can be tackled. EU institutions, Member States and legal or natural persons can instigate proceedings under this article on grounds of lack of competence, infringement of an essential procedural requirement, infringement of the treaties or of any rule of law relating to their application or misuse of powers. However, the threshold for individuals or groups to launch an action under this article is high. More particularly, the article provides that any natural or legal person may commence such proceedings against an act that is of "direct and individual concern to them". As noted by Fitzpatrick, it is "nigh on impossible" 56 for parties who are likely to instigate such challenges, such as affected individuals in bailouts, trade unions or civil society organizations, to meet the aforementioned procedural requirement. On the contrary, this article makes it much easier for Member States and EU institutions to launch such challenges since the only procedural requirement is a time limit. However, apart from the European Parliament, it is probably unlikely that Member States or other institutions will take such measures. ${ }^{57}$

\section{Position of the CJEU to Crisis-Related Case Law}

In the landmark case of Pringle, the CJEU was faced, inter alia, with the position that the ESM Treaty was incompatible with the general principle of effective judicial protection and the principle of legal certainty. To this end, an analysis of whether or not the ESM fell within the scope of the Charter was undertaken. Relevant to this was the meaning and relevance of Article 51 therein. Article 51(1) stipulates that the provisions of this Charter are addressed to the institutions, bodies, offices and agencies of the Union with due regard to the principle of subsidiarity and to the Member States, only when they are implementing Union Law. Article 51(2) holds that the Charter does not extend the field of application of Union Law beyond the powers of the Union or establish any new power or task for the Union, or modify powers and tasks as defined in the treaties. The CJEU concluded that the Member States were not implementing Union Law within the meaning of Article 51(1) of the Charter when they established the ESM and that the treaties do not confer any competence on the Union to establish such a mechanism. Moreover, it found that no obligations arise from the actions of EU institutions acting within the framework of the ESM as "the duties conferred on the Commission and ECB within the ESM Treaty...do not entail any power to make decisions of their own" ${ }^{58}$ Further, the activities pursued by those two institutions within the ESM Treaty only commit the ESM. So, essentially, the CJEU views the 
ESM as an entity providing loans to Member States under strict conditionality, as an entity functioning outside EU Law and, therefore, not bound by it. This is yet another indicator demonstrating the stark prioritization of an economic constitution in the EU, with the Court essentially standing as a bystander to this procedure, notwithstanding the potential violations of EU Law as a result of activities occurring with the ESM, its status and actions in relation to the Charter, but also in relation to treaty provisions, such as Article 263 on reviewing the legality of acts of the EU. A mirror approach of Pringle was adopted by the CJEU in Gauweiler. ${ }^{59}$ This case looked at the European Central Bank's Outright Monetary Transactions Programme and found them to be legal. This case is significant for the present discussion as it illustrates the paradigm of financial stability and does so by embracing Pringle principles. As argued, this case

builds on Pringle providing normative legitimization to the austerity model while granting the ECB a distinct role in monetary policy but also in shaping the general economic policy of the Union. ${ }^{60}$

Further, the position put forth in Pringle, regarding the scope of EU Law in relation to the ESM, was also discussed in a series of Cyprus bank restructuring cases, such as (Mallis and others ${ }^{61}$ ), where the CJEU reiterated the Pringle position, making a parallel between the activities of the Commission and the ECB in the ESM and in the Eurogroup and noting that, even though these two participate in the Eurogroup meetings, this "cannot result in the statement at issue being considered to be the expression of a decision-making power of those two EU institutions" ${ }^{62}$ It subsequently underlined that the Eurogroup is not an EU institution and its decisions cannot, therefore, undergo judicial review under Article 263 TFEU. On a more positive note regarding European responsibility in relation to anti-crisis strategies, the case of Ledra Advertising maintained the Pringle position that the ESM functioned outside the EU legal order but noted, importantly, that this

cannot prevent unlawful conduct linked...to the adoption of a memorandum of understanding on behalf of the ESM from being raised against the Commission and the ECB in an action for compensation... ${ }^{63}$

In particular, it stressed the role of the Commission under Article 17(1) in relation to promoting the Union's interest. In conceptualizing the role of the Com-

59 Judgment of 16 June 2015, Gauweiler, C-62/14, EU C:2015:400.

60 T. Tridimas \& N. Xanthoulis, 'A Legal Analysis of the Gauweiler Case Between Monetary Policy and Constitutional Conflict', Maastricht Journal of European and Comparative Law, Vol. 23, No. 1, 2016, p. 17.

61 Shaelou \& Karatzia, 2017, (forthcoming).

62 Judgment of 20 September 2016, Mallis and Others, C-105/15 P to C-109/1, EU:C:2016:702, para. 57.

63 Judgment of 20 September 2016, Ledra Advertising Ltd and Others, C-8/15 P to C-10/15 P, EU:C: 2016:701, para. 55 . 
mission in this manner and recognizing its individual responsibility, notwithstanding that the ESM was considered to fall outside the ambit of EU Law, the Court looked at whether the Commission contributed to the appellants' right to property as provided for by the Charter. This was, therefore, a move in the direction of recognizing responsibility of the EU institutions involved in anti-crisis activities, even though the final decision was to find no breach of Union Law. However, there is a clear shift in position, with the CJEU recognizing the possibility of finding liability of EU institutions, such as the ESM, who act within ghost frameworks, notwithstanding that the ESM has been deemed to function outside the EU legal framework.

Some further, relatively positive developments include Florescu, in which the CJEU was faced with the question of whether the Memorandum of Understanding under consideration can be regarded as an act of an EU institution within the meaning of Article 267 TFEU. The CJEU answered in the affirmative, finding that as "an act whose legal basis lies in the provision of EU Law...and concluded, in particular, by the European Union, represented by the Commission, the Memorandum of Understanding constitutes an act of an EU institution within the meaning of Article 267(b) TFEU". ${ }^{64}$ In the recent Advocate General opinion in Associação Sindical dos Juízes Portugueses, ${ }^{65}$ the referring court posed the question of whether national legislation is compatible with the principle of judicial independence, which, in its view, derives from Article 19(1) TEU and Article 47 of the Charter. The referring court held that the measures limiting expenditure were regulated and supervised by the EU institutions in the framework of financial assistance. As such, the Advocate General proposed that the CJEU should answer the question for a preliminary ruling.

Therefore, threshold issues do remain as a result of the formulation of Article 263 TFEU, which renders arduous the procedure to challenge the legality of a Union act by interested individuals and groups. In relation to the CJEU and its position vis-à-vis the role of the institutions involved in the anti-crisis strategy of the Union, there has been some gradual advancement in relation to the position and role adopted by the CJEU in relation to the responsibilities of EU institutions in the sphere of the anti-crisis strategy. Although, starting with Pringle, the CJEU kept out of the way of the institutions' mandates and activities, this slowly changed with later cases, such as Ledra Advertising, which, notwithstanding the outcome of the case, could be considered as a catalyst for such change and a recognition that, notwithstanding the functioning of entities, such as the ESM, outside the EU framework, the obligations of individual EU institutions exist. So, while the argument of the CJEU washing its hands of any responsibility with regard to the anti-crisis strategy of the Union and the absolute prioritization of the economic constitution could be put forth in, for example, Pringle, the Court has now recognized that, even if mechanisms do function outside the EU legal order, the EU institutions themselves are still obliged to function within that order. This is a positive development in ensuring some kind of checks and balan- 
ces to the prioritization of the economic constitution as the realm in which the crisis is tackled. Nevertheless, more rigorous and transparent monitoring could only be ensured if mechanisms, notably the ESM, were to be deemed to function in the EU order. Only then can the judicial body of the Union be truly effective in monitoring the constitutional developments of the EU and stand as a robust obstacle to the absolute prioritization of the economic constitution.

\section{F Sustainability of Socio-economic Rights in Times of Crises: Way Forward}

The current crisis, and the strategy adopted by the Union to tackle it, is very much founded on fiscal consolidation with little or no regard for the impact of its strategy on economic and social rights. On a normative level, the ease with which this became a reality reflects the ever-existing discussions and positions regarding the nature of economic and social rights as, inter alia, progressively realizable with obstacles to their justiciability. As argued, tackling the very foundation of the normative conceptualization of economic and social rights may be "overly optimistic". ${ }^{6}$ Thus, with a view to ensuring a long-term and efficient protection of social and economic rights in all contexts and situations, the approach adopted by international institutions and countries to this generation of rights needs to be drastically modified and this article puts forth some more practical ideas on how the sustainability of social and economic rights in a time of crisis can be promoted. These include the reconceptualization of the interrelationship between economic and social rights and the crisis and the improvement of the infrastructure surrounding the need and implementation of austerity measures.

\section{Reconceptualizing Rights and the Crisis: Long-Term Solutions}

To date, the anti-crisis strategy of the EU has been fiscal reconsolidation with little or no regard to social impact, with economic and social rights being treated literally as the poor relative of the Union's approach. Indicative of this was the absence of any reference in the legal documents of the lenders to the Chapter on Solidarity of the Charter or the revised European Social Charter. There is one mention of the right to collective bargaining in the two-pack. This conspicuous lack of reference to relevant documents or themes is one of the indicators demonstrating the focus on the economic constitution without due regard to social aspects and, particularly, the protection of social and economic rights in the framework of the adopted austerity measures and the overall approach taken to the crisis. As argued, the current reality reflects that "the market-liberal economic reason has conspicuously overruled the European social constitution" ${ }^{67}$ Another such indication was the negotiation process for the amendment of Article 136 TFEU, in which the European Parliament requested the insertion of the strict conditionality provision to be in accordance with the principles and objectives of the Union as laid down in treaties. This recommendation was rejected by the 
European Council. This rejection not only reflects the disregard of incorporating treaty obligations and Union interests, such as the promotion of solidarity and non-discrimination, but also the ousting of the only elected institution of the Union in any anti-crisis process, as described in Section D.III. Given the almost absolute disregard of human rights in the realm of the European anti-crisis strategy, other institutions have attempted to assert their position, albeit with little success. The European Committee of Social rights, which monitors the revised European Charter of Social Rights has, for example, decided on several cases brought by Greek trade unions and civil society organizations. The decisions emanated from the premise that economic crises should not lead to a deterioration of economic and social rights. In one case, the Committee found that

governments are bound to take all necessary steps to ensure that the rights of the Charter are effectively guaranteed at a period of time when beneficiaries most need the protection. ${ }^{68}$

This is a particularly significant position and very different from that put forth by the CESCR in its relevant letter insofar that it does not use the crisis as a framework potentially to justify restriction to this generation of rights but, rather, that it renders their protection even more significant. However, at the end of the day, organizations, such as the aforementioned Committee, can only provide criticism to states parties without much repercussion if these states do not follow such criticism not only due to the power of the Committee itself but also due to the nature of state obligations, which are to take steps, to a maximum of their available resources, progressively to realize the rights of the Covenant. Either way, the extent to which states parties had practical leeway to manoeuvre in light of the strict conditions imposed by the lenders is doubtable.

If the Union is to achieve sustainable solutions to the crisis and to the protection and promotion of economic and social rights, the latter need to be reconceptualized, more generally, but also within the framework of crisis responses. Economic and social rights must no longer be considered as competing interests and rights that necessarily have to be put aside for the greater good of fiscal revamping. To achieve this, the Union and its Member States must move away from the rhetoric of emergency and crisis which constitute the lens through which economic and social rights are perceived (if at all) in anti-crisis strategies. Moreover, as recommended by the Council of Europe Parliamentary Assembly, in times of 'unbridled economic liberalism,' focus should be placed on protecting the general principles of a social market economy and strengthening the welfare state through an anthropocentric approach. ${ }^{69}$ In reports on crisis-stricken countries, such as Cyprus, the Council of Europe Commissioner for Human Rights underlined that emergency situations, such as a financial crisis, should not be a free pass for the automatic restriction of economic and social rights and the deteriora-

68 European Committee of Social Rights, Conclusions, 2009, Vol. I, para. 17.

69 Resolution 1884 (2012) austerity measures - a danger for democracy and social rights parliamentary assembly. 
tion of the living conditions of vulnerable groups. ${ }^{70}$ However, the Commissioner did not just remain at this but developed other ideas in relation to economic and social rights in a crisis. More particularly, he suggested that such times should be viewed as

windows of opportunity to overhaul their national human rights protection systems and reorganise their administration in order to build or reinforce the efficiency of national social security systems, including social safety nets that should be operational when necessary.

This position is miles away from the strategy of the Union, emanating from the conditions and requirements of an economic constitution and even more developed than the position of the CESCR, as put forth in the letter discussed in Section D.I, which endorsed the potentially inevitable need to limit such rights in times of crisis and set out some abstract safeguards on how this must be done. If the EU is to adopt a sustainable protection framework for social and economic rights, which are the first victims in a crisis, the system and approach need to be re-designed. Economic development must not be seen as an opposite pursuit to social and economic rights but, instead, as part and parcel of an effective anti-crisis strategy achieving economic development through a human rights based approach. This approach was also called for by the Council of Europe's Parliamentary Assembly, which recommended a "profound reorientation of current austerity programmes, ending their quasi-exclusive focus on expenditure cuts in social areas". ${ }^{71}$ The Assembly proposed moving away from cutting public expenditure and replacing it with raising taxes on higher income categories and property wealth. The Assembly also recognized that sustainable economic development needs sustainable solutions such as the creation of new employment opportunities, support of young people in transition from education to the labour market and more. ${ }^{72}$ This can facilitate sustainable economic development and, by default, place the promotion of economic and social rights at its epicentre. Through such approaches, there are no longer competing objectives of human rights promotion and economic development (as is the case today), no prioritization of tasks and themes and no poor relatives.

\section{Reconceptualizing Rights and the Crisis: Short-Term Solutions}

Being realistic on the functioning and approach of the EU today in relation to the crisis, the above ideas regarding how the crisis needs to be reconceived will take time and, importantly, political and institutional will. In the meantime, however, the continuum of an almost absolute economic constitution and the lack of regard of the measures on economic and social rights need to be tackled in a more

70 Report by the Commissioner for Human Rights of the Council of Europe following his visit to Cyprus from 7-11 December 2015, para. 112.

71 Resolution 1884 (2012) austerity measures - a danger for democracy and social rights parliamentary assembly, para. 6 .

72 Ibid., para. 7. 
immediate fashion. For this purpose, austerity measures need to be perceived as a necessary reality (at least for a while). To this end, such measures need to be properly conceptualized and applied. First, the CESCR has noted, in abstract terms of course, that any deliberate retrogressive measures

would require the most careful consideration and would need to be fully justified by reference to the totality of the rights provided for in the Covenant and in the context of the full use of the maximum available resources. ${ }^{73}$

The letter of the CESCR, referred to in Section D.I, noted that measures must be temporary, implemented only during the crisis, be necessary and proportionate and not discriminatory, while the minimum core content of rights must be identified and protected at all times. No further extrapolation was given in relation to the substantial meaning of the safeguards.

In addition, the obligations of involved parties need to be clarified. One of the central issues to have come about in the EU's anti-crisis strategy has been the difficulty in the "pinpointing of a violator and the assertion of responsibility". ${ }^{74}$ So, while Member States themselves were part of the process, implementing the austerity measures on the ground and entering into agreements with the lenders in the first place, it was the lenders themselves who put forth strict conditionality requirements. Moreover, as discussed in Section D.III, national bodies, such as parliaments, appeared simply to be taking supra-national orders, rather than participating legitimately in any process. Therefore, who bears the responsibility or responsibilities for the deterioration of economic and social rights during this difficult period, both as this resulted from the crisis itself and, importantly, from the strategy subsequently adopted by the European Union? In the realm of crisis-related case law, as with Ledra Advertising onwards, the CJEU recognized the obligation of the Union institutions, such as the European Commission, which, under Article 17 of the TEU, must promote the interests of the Union and ensure the application of the treaties. The above depicts an intricately complex situation where the role of Member States themselves is limited to the point where the involvement of nationally elected bodies can be considered a democratic facade, where mechanisms developed for lending purposes within the EU have been deemed to fall outside the EU legal order and where the realization of the individual responsibilities of EU institutions in the process did not come about from the onset. All of this occurring with an economic constitution where fiscal reconsolidation is the key priority, with little or no regard to the socio-economic aspects of the adopted measures. Although the adoption of such a constitution has been made possible by the very perception of the nature of economic and social rights, which is tricky to change in the short-term, what can be developed is the role of national institutions in this process, granting them a genuine role in negotiating and Cultural Rights to States parties to the International Covenant on Economic, Social and Cultural Rights, CESCR/49th/SP/MAB/SW. 
and subsequently implementing austerity measures as well as a reconceptualization of the relationship between anti-crisis mechanisms, notably the ESM (not just EU institutions) in the EU legal order. If these two are achieved, then at least democratic legitimization of measures will be realized and, therefore, better accepted by the countries involved as well as the legitimization of the mechanisms themselves.

Further, if austerity measures exist, as it is foreseen that they will exist considering the current anti-strategy approach of the Union, their impact needs to be properly assessed. As noted by the FRA, Member States and the EU should carry out an assessment of the measures' impact before and after their implementation. ${ }^{75}$ Importantly, the FRA underlined the need to incorporate human rights institutions in this assessment and noted that, for this purpose, such institutions should be strengthened so as to be able to conduct such activities. Impact assessment was also put forward as a necessary practice by the Council of Europe Human Rights Commissioner who underlined that this process must be 'transparent and inclusive' and occur in cooperation with human rights institutions and civil society organizations. ${ }^{76}$ When considering the impact of measures, before and after their implementation, particular attention needs to be placed on the identification and protection of vulnerable groups. In this sphere, the Council of Europe Human Rights Commissioner suggested to crisis-stricken countries, such as Cyprus, the incorporation of social safety nets as part of the national social protection system in different forms such as cash, in kind, fee waivers on services and income support. ${ }^{77}$ In fact, this recommendation could be the way forward given that social competences essentially fall within the capacity of Member States. On a practical level, this can happen insofar as the lending institutions allow for fiscal leeway for the countries to manage such safety nets. In this sense, social and economic rights could constitute the bridge between Member States and the European Union and constitute an effective realm in which the usurping of the EU's constitutional arena by the economic constitution can be overturned.

\section{G Conclusion}

This article has focused on social and economic rights and the need to ensure the sustainable protection of such rights in a crisis. This focus emanates from the reality that economic and social rights are placed under direct threat by the crisis itself but also by austerity measures adopted by the EU to tackle the crisis. However, this by no means implies that other groups of rights, such as civil and political rights, are not affected by the crisis. Moreover, the effect of the crisis on the human rights framework of a nation and/or a region does not end with the effect on the generations of rights but also includes the rise in phenomena such as rac-

75 Fundamental Rights Agency Working Paper, 'Protecting Rights during the Economic Crisis', 2010, p. 47.

76 Report by the Commissioner for Human Rights of the Council of Europe following his visit to Cyprus from 7-11 December 2015, para. 114.

77 Ibid., para. 42. 
ism and xenophobia, given that groups such as refugees and asylum seekers are habitually presented by entities such as the media and political parties and perceived by the general public as, for example, benefit scroungers. Further, in an analysis of relevant Eurobarometres, it was demonstrated that xenophobia is higher among unemployed persons, ${ }^{78}$ thereby, reflecting the link between the impact of the crisis and the rise in intolerance. Europe's history reflects how dire economic situations can lead to social exclusion and persecution (and in the case of, for example, World War II - extermination). A plethora of institutions such as the FRA, the OSCE Office for Democratic Institutions and the European Council against Racism and Intolerance, have noted that groups such as migrants, minorities and other vulnerable groups become scapegoats in a time of crisis. ${ }^{79}$ As such, tackling the crisis in a more sustainable manner, by placing social and economic rights at the epicentre of a strategy and moving away from the competitive attitude of economic prioritization versus human rights, will not only benefit the rights themselves but will preserve the general spirit and values of the Union, as provided for by Article 2 TEU.

In assessing the crisis that has hit the EU and, in particular, the anti-crisis strategy adopted by the institutions, it becomes apparent that an economic constitution is, as in the Rome Treaty era, governing the functioning of the Union without due regard for its social counterpart. This reinstatement of economic dominance has made silent treaty changes and has impacted the very foundations of the Union, which are no longer solely economic. For example, the above analysis demonstrates that the ever-important Union value of solidarity has come to mean financial solidarity but, essentially, for non-solidarity purposes (i.e., nondefaulting countries safeguarding their own prosperity by facilitating the proper functioning of the Eurozone). In order to ensure the sustainability of economic and social rights and prevent the deterioration of other rights and the rise of aforementioned phenomena, the EU institutions and Member States need to adopt a responsible approach to this issue, working on an effective and well-rounded protection of social and economic rights within any anti-crisis strategy rather than viewing them as the first and easiest targets to facilitate fiscal consolidation. It is imperative to note that such changes need to be made from a centralized level (the EU) first as the lenders are the ones managing the process. Member States should also be active in assessing strategies, both pre- and post-implementation of any fiscal or social alterations on the ground, although sufficient leeway needs to be granted to them to do so. However, insofar as the economic constitution is the one monopolizing Union strata, this is not a possibility because it is, essentially, the rise and prioritization of this constitution that has led to the above-described results. As such, shift needs to be made to place, at least, equal emphasis on the integration and protection of economic and social rights, as provided for in the treaties. What is significant is not to view the economic and social

79 Fundamental Rights Agency, 'The European Union as a Community of Values: Safeguarding Fundamental Rights in Times of Crisis', 2013, p. 17. 
constitutions as competing but, rather, as synergies that need to be pursued together if sustainable fiscal consolidation that incorporates the human rights and human person element is to be achieved. The EU institutions functioning within the framework of anti-crisis activities do not enjoy immunity, with the CJEU having recognized that, although the ESM functions outside the European legal order, the institutions themselves do not. This is the first step in working towards the necessary structures of ensuring a proper conceptualization and understanding of the social constitution of the EU which pre-requires, for example, the respect of treaty articles, such as Article 2 of the TEU, and ensuring that the Commission is, under Article 17 of the TEU, a guardian of the Union's interests and its values. Structural changes still need to be made if the social constitution is to be an adequate part of the Union's reality, such as the increased role of elected entities at a national level but also at a European level, for purposes of democratic legitimacy.

To date, social and economic rights have "proved to be rather toothless in resisting or redirecting" 80 anti-crisis strategy such as spending cuts. If the scene is to alter, there needs to be a normative shift from the prioritization of the economic constitution of the Union, which has led to silent treaty changes and has had a dismal effect on the enjoyment of social and economic rights by inhabitants of the EU and, particularly the most vulnerable. In sum, normative strategic reconstruction of this constitution needs to be effectuated in addition to alterations such as increased monitoring of anti-crisis mechanisms, in a democratic and transparent way, and a rise in the involvement of national entities, in particular elected bodies. Moreover, there needs to be an absolute reconsideration of the relationship between a crisis and economic and social rights, moving far away from the emergency rhetoric to a constructive human rights based approach to the sustainable reconsolidation of an ill economy. Last, but not least, although there exist articles and analyses on the negative impact on the exercising of social and economic rights as a result of the Union's crisis and its anti-crisis strategy, there is also the other worrying, yet significant, element that may initially be wrongly perceived as being too far-detached to be linked to the present discussion, namely the interrelation between austerity measures and, for example, mental health issues, substance abuse and suicide. ${ }^{81}$ On this note, if the Union is truly "a community based on the rule of law" 82 and if the founding principles include those of solidarity and non-discrimination, urgent steps in the abovedescribed direction need to be taken. 